\title{
Inventory of managed aquifer recharge sites in Europe: historical development, current situation and perspectives
}

\author{
C. Sprenger ${ }^{1}$ N. Hartog ${ }^{2}$ - M. Hernández ${ }^{3}$ - E. Vilanova ${ }^{4}$ - G. Grützmacher ${ }^{5}$.

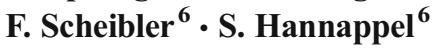

Received: 8 June 2016 / Accepted: 6 February 2017 /Published online: 16 March 2017

(C) The Author(s) 2017. This article is published with open access at Springerlink.com

\begin{abstract}
Different types of managed aquifer recharge (MAR) schemes are widely distributed and applied on various scales and for various purposes in the European countries, but a systematic categorization and compilation of data has been missing up to now. The European MAR catalogue presented herein contains various key parameters collected from the available literature. The catalogue includes 224 currently active MAR sites found in 23 European countries. Large quantities of drinking water are produced by MAR sites in Hungary, Slovakia, the Netherlands, Germany, Finland, Poland, Switzerland and France. This inventory highlights that, for over a century, MAR has played an important role in the development of European water supply and contributes to drinking-water production substantially. This development has occurred autonomously, with "trial-and-error" within the full range of climatically and hydrogeologically diverse conditions of the European countries. For the future, MAR has the potential to facilitate optimal (re)use and storage of available
\end{abstract}

C. Sprenger

christoph.sprenger@kompetenz-wasser.de

1 Kompetenzzentrum Wasser Berlin GmbH, Cicerostr. 24, 10709 Berlin, Germany

2 KWR - Watercycle Research Institute, Groningenhaven 7, 3433 PE Nieuwegein, The Netherlands

3 Cetaqua, Water Technology Center, Carretera d'Esplugues 75, Cornellà de Llobregat, 08940 Barcelona, Spain

4 Amphos21 Consulting SL, Passeig de Garcia Fària, 49, 08019 Barcelona, Spain

5 Berliner Wasserbetriebe, Neue Jüdenstraße 1, 10179 Berlin, Germany

6 HYDOR Consult GmbH, Am Borsigturm 40, 13507 Berlin, Germany water resources and to take advantage of the natural purification and low energy requirements during MAR operations. Particularly with respect to the re-use of wastewater treatment-plant effluent and stormwater, which is currently underdeveloped, the use of MAR can support the public acceptance of such water-resource efficient schemes. Particularly for the highly productive and urbanized coastal zones, where the pressure on freshwater supplies increases by growing water demand, salinization and increased agricultural needs for food production (such as along the Mediterranean and North Sea coasts), MAR is expected to be increasingly relied on in Europe.

Keywords Artificial recharge $\cdot$ History of hydrogeology . Future $\cdot$ Europe

\section{Introduction}

Managed aquifer recharge (MAR) describes the intentional recharge and storage of water into an aquifer for subsequent recovery or for environmental benefits. MAR can be used to store and treat water in an appropriate aquifer from a variety of source waters, including river water, treated effluent, stormwater, desalinated seawater, rainwater, and even groundwater from other aquifers. MAR is a cross-cutting technology applicable for the drinking water supply, for processing water for industry, for irrigation and for sustaining groundwater dependent ecosystems. MAR relies on naturally occurring processes in the subsurface such as mechanical filtering, sorption and biodegradation, and is often applied in combination with engineered treatment systems, as pre-treatment prior to recharge and post-treatment after recovery.

The European MAR catalogue presented herein contains data from the literature about the MAR type, coordinates, year 
of first operation and closure, reason for closure, operational scale, aquifer properties (hydraulic conductivity, target aquifer thickness), horizontal aquifer passage, residence time during subsurface passage, recovery rate/share of bank filtrate, source water type and end-use. This catalogue is aimed at (1) outlining the historical origins, (2) describing the current situation and (3) giving perspectives of future developments of MAR in Europe.

\section{Materials and methods}

\section{MAR classification}

There is a large variety of different MAR types, which can be classified based on the recharge and storage technique into four major groups (Table 1).Enhanced infiltration techniques rely on gravitational infiltration and percolation, and include different surface-spreading methods (areal recharge), point/ line recharge and in-channel modifications. Surfacespreading methods are among the simplest and most widely applied MAR techniques. In such methods, the source water is spread over a permeable land surface to enhance the infiltration and percolation to the groundwater body. Most of the existing large-scale MAR sites in Europe make use of this technique, and typically utilise infiltration ponds to increase the groundwater availability. Soil aquifer treatment (SAT) describes the infiltration and percolation of reclaimed water (treated wastewater) through soil and aquifer passage. Due to the lower quality of source water, SAT systems are often operated in wet and dry cycles to allow for maintenance (e.g., mechanical removal of clogging layer) or to restore aerobic conditions in the infiltration zone. During point or line recharge, source water is infiltrated either in elongated (e.g., shafts, drains) or punctual (e.g., abandoned dug wells, bore holes) recharge structures.

In-channel modifications are structures or measures applicable to stream or channel beds. Riverbed scarification is a measure to enhance the riverbed recharge by mechanical removal of the impermeable top layer in the riverbed. Sand dams are constructed in non-perennial rivers where during periods of high flow, the suspended solids in the stream flow accumulate upstream of the dam over time. Runoff water can easily infiltrate these highly permeable deposits, creating a small-scale artificial aquifer upstream of the dam. Sand dams are often found in Sub-Saharan countries.

Induced bank filtration (IBF) describes the infiltration of surface water induced by pumping from a nearby well. In opposite to bank filtration, which is occurring due to losing river conditions, induced bank filtration emphasizes the purposeful abstraction of surface water by wells. During bank filtration, water quality improvement (treatment) of the induced surface water is commonly observed. IBF sites often consist of several wells situated in a line parallel or perpendicular to the bank of the surface water body. Induced bank infiltration sites are typically installed near perennial streams and lakes that are in hydraulic contact with the adjacent aquifer.

Well injection techniques are used where thick, lowpermeability strata overlie the target aquifer(s). Well injection methods include aquifer storage and recovery (ASR), aquifer storage transfer and recovery (ASTR) and aquifer storage (AS). ASR is defined as "the storage of water in a suitable aquifer through a well during times when water is available, and the recovery of water from the same well during times when it is needed" (Pyne 2005), whereas ASTR includes an
Table 1 Classification and overview of MAR types included in the catalogue

\begin{tabular}{ll}
\hline Recharge technique and main MAR type & Specific MAR type \\
\hline Enhanced infiltration & \\
Surface-spreading methods (areal recharge) & Infiltration ponds \\
& Soil aquifer treatment (SAT) \\
& Excess irrigation, ditches, trenches, sprinkler irrigation \\
& Well/borehole infiltration \\
Point or line recharge & Reverse drainage, shaft recharge \\
& Check dams \\
In-channel modifications & Riverbed scarification \\
& Sand dams \\
& Riverbank filtration \\
Induced bank filtration (IBF) & Lake bank filtration \\
Well injection & Aquifer storage and recovery (ASR) \\
& Aquifer storage, transfer and recovery (ASTR) \\
& Aquifer storage as hydraulic barriers (AS) \\
Enhanced storage & Subsurface dams
\end{tabular}


aquifer passage between the injection and abstraction well. ASTR serves to bridge seasonal gaps in source water by storing water in times of excess and recovering it in times of demand. The stored water is flowing according to the local hydraulic gradient toward the point of abstraction. ASTR is more appropriate in dry climates with pronounced seasonal water availability, but is also found in moderate climatic zones, e.g., the Netherlands. The increased transport component for all injected water as compared to ASR, enhances the removal potential for, e.g., bacteriological parameters. Also, enhanced mixing with native groundwater will occur, which can be seen as a positive or negative aspect, depending on location-specific conditions.

Water storage to bridge seasonal gaps in water supply is often the primary goal when applying this technique. Aquifer storage (AS) primarily aims at groundwater replenishment in the target aquifer, e.g., to counteract seawater intrusion. Subsurface dams, which are rarely used in Europe, do not lead to additional recharge but enhanced groundwater storage where required. This type is therefore classified as enhanced storage.

Other techniques such as rooftop water harvesting (also called rainwater harvesting), is a method for collecting source water (in this case rain) in the capture zone. Rooftop water harvesting can be combined with injection or infiltration techniques as per local conditions and requirements, and therefore, is not considered as a MAR technique.

\section{Data availability, coverage and limitations}

The data presented herein were compiled mostly from scientific publications (i.e., peer-reviewed papers, textbooks, $\mathrm{PhD}$ theses) accounting for $42 \%$ of all literature sources. Web pages of MAR operators account for $25 \%$, presentations (both talks and posters) for $14 \%$, technical reports and documents for $10 \%$, reports from governmental and non-governmental projects $4 \%$, and personal communication with specialists and operators, and newspaper articles account for 5\%.

The European MAR catalogue does not claim to be a comprehensive database including all existing MAR sites in Europe (which is virtually impossible). The lack of data for some countries does not necessarily mean the lack of MAR sites, but can rather be attributed to the fact that language barriers restricted the literature research to languages spoken by members of the author team (i.e., English, Spanish, German, Polish, Dutch and French).

The database contains 278 MAR sites, out of which 56 sites were shut down before 2013. In most cases, the reason for closure is not reported, but many of the closed sites were used as pilots for a limited period of time. At other sites, operation has been suspended temporarily or was shut down entirely due to economic, technical or political reasons.

Data presented herein build on reports from the DEMEAU project (Hannappel et al. 2014), but have undergone substantial changes. Selected data from the European MAR catalogue are available on a web-based geographic information system (GIS) platform and incorporated into a global inventory of MAR sites developed by the International Groundwater Resources Assessment Centre (IGRAC 2016). Maps presented herein were created with the public domain software QGIS 2.8.3; the coordinate reference system is ETRS89, Lambert Azimuthal Equal Area.

\section{Quality assurance and plausibility control}

Several persons with various professional backgrounds contributed to data acquisition. Besides the risk of typing error during data entry, many other factors, e.g., false interpretation, translation errors, outdated information sources, will challenge the quality of the collected data. Thus, following the data acquisition period, various quality control measures were carried out to ensure a high level of data integrity. Identified outliers and conspicuous extreme values of the database's numerical fields were double-checked using the respective references. Besides these relatively simple statistical tests on individual fields, logical checks were performed between related parameters in order to identify data gaps. Implausible or unlikely combinations of parameter values were also checked and corrected if necessary.

\section{Results and discussion}

\section{Historical development of MAR in Europe}

Information on the year of first operation and the year of closure allows outlining the historical development of MAR in Europe. The modern history of what is called MAR today begins with two techniques which are most prominently represented in the MAR catalogue: (1) induced bank filtration and (2) surface-spreading methods (Fig. 1).

The first reported MAR site in Europe was in Glasgow (UK) where in the year 1810 the Glasgow Waterworks Company constructed a perforated collector pipe parallel to the Clyde River (Ray et al. 2002) and abstracted bank filtrated water (BMI 1985; note this site is not shown in Fig. 1 because it seems to be historically isolated). This method was successful at the beginning and many other cities in the UK (e.g., Nottingham, Perth, Derby, Newark; Ray et al. 2002) adopted the idea; thus, the 1860 s became the first heyday of "naturally filtered water" in the UK (BMI 1985). However, many of these early sites experienced problems with decreasing well performance and had to be abandoned in later years (BMI 1985); nevertheless, the idea of "naturally filtered underground water" was born and spread to continental Europe, where it was soon adopted by cities in the Netherlands, Belgium, Sweden, France, Austria and Germany. The 
Fig. 1 Outline of the historical development of MAR in Europe showing the number of MAR sites opened or closed per decade between the 1870 s and 2000 s

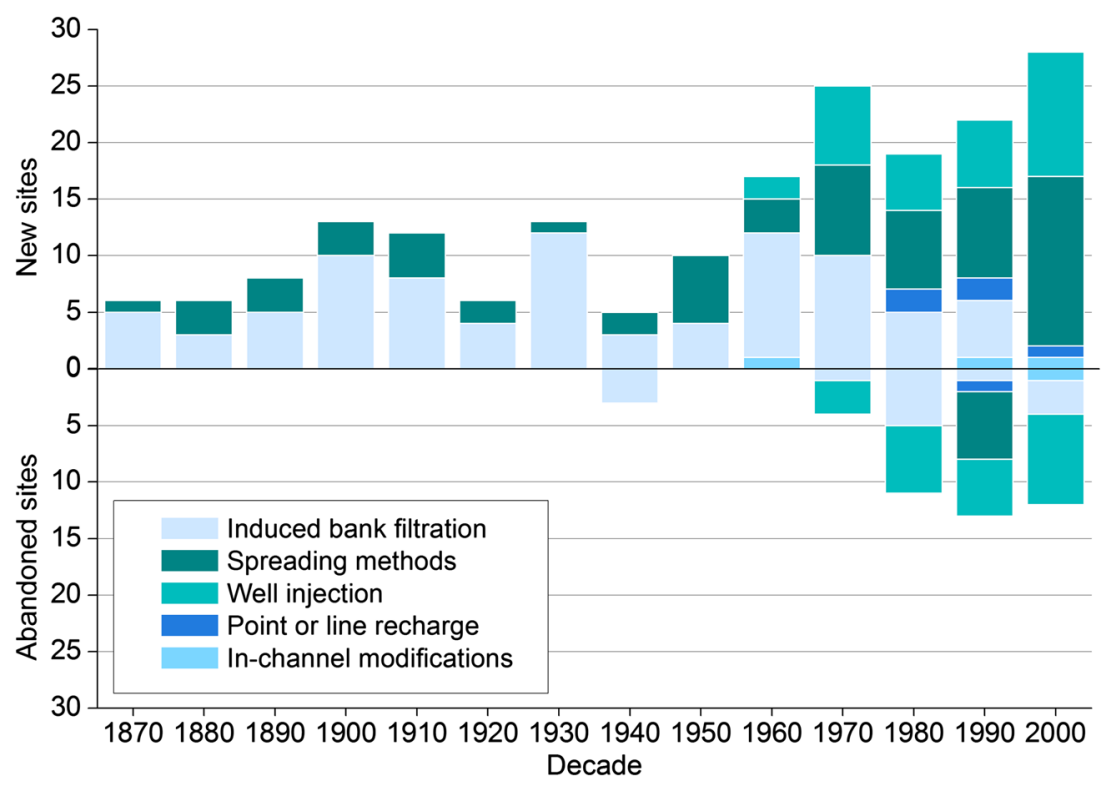

scientific investigation of "artificial underground water" in Europe began with the water engineers Dupuy, Belgrand, Salbach, Thiem and Richert in the late 19th century (Richert 1900). The progressing industrialization in the 19th century and growing population in European cities presented the water suppliers with new challenges. The traditional water supply based on surface water was impaired by increasing contamination from the new industries and improper sanitation. At that time, based on the experiences in the UK, Thiem proposed the application of riverbank filtration to cope with degrading hygienic surface-water quality and increasing water demand; thus, the pioneers of MAR in Germany can be found at the industrialization hubs close to the Rhine River (e.g., Water Works Düsseldorf 1870), the Ruhr River (e.g., WW Essen 1875), the Elbe River (e.g., WW Saloppe 1875, WW Hosterwitz 1908) around Dresden, and in the Berlin area (e.g., WW Müggelsee, switched to groundwater in 1904-1909, WW Tegel 1901-1903). To increase the abstracted water quantity, many water works constructed infiltration ponds which were often situated on the land side of the abstraction well galleries. Similar to the development in Germany, riverbank filtration (RBF) and infiltration ponds found application in the Netherlands, Sweden and Switzerland - for example, in the Netherlands, the first known RBF-based water supply was reported to have started its operation in 1890 (Stuyfzand 1989). The first MAR site in Switzerland started its operation in Basel "Langen Erlen" in 1912. Eastern European cities then followed and in Hungary the first RBF site was installed north of Budapest on a Danube island (Szentendre Island) in the 1920s (Homonnay 2002); to date, this MAR system is the main drinking water source for Budapest (Homonnay 2002). Additional RBF sites have been developed on other Danube islands (e.g., Csepel) and nowadays several RBF sites exist along the rivers of Raba, Drava, Ipoly, Sajo and Hernad
(Homonnay 2002). In Romania the MAR history starts with the operation of the Iasi water supply system at the Moldova River in 1911 and the cities of Cluj Napoca followed in 1935 with conjunctive use of RBF and infiltration ponds and Bacau in 1961 (Rojanschi et al. 2002). In Finland the first water plant using groundwater replenishment by infiltration ponds started its operation in 1929 in Vaasa (Tapio et al. 2006). A few other plants were developed before and after World War II, but the systematic development of MAR in Finland started in the 1960s (Tapio et al. 2006). It is reported that in the year 1992 about 20 water suppliers relied on different MAR types mainly constructed in the 1970s and by 2002, already 25 operating water works utilized MAR in Finland (Tapio et al. 2006). Finally, Tapio et al. (2006) report that after several decades of experience with MAR, this technique is continuously favored by water suppliers.

Research and development of well injection methods began in the 1960s. These early sites were mostly situated in the Netherlands where pilot-scale trials began. Stuyfzand et al. (2012) report that many of these early ASR sites have been closed due to clogging problems. An exception is located in Barcelona, Spain, where a dozen ASR wells were constructed in the early 1970s and are still active today (Hernández et al. 2011). Here, the high transmissivity of the target aquifer (up to $40,000 \mathrm{~m}^{2} /$ day) and low turbidity ( $<1 \mathrm{NTU}$ ) of source water are key parameters associated with the good long-term system performance (Hernández et al. 2015). Cleaning cycles consist of pumping episodes of 15 days with a flow rate four times higher than the injection flow (Azcon and Dolz 1978). Maintenance strategies and clogging aspects are known to be important to consider for MAR practices, but were only rarely reported in the available literature for the European sites. However, in addition to turbidity, as illustrated by the example given, redox mixing and clay swelling are some of 
the additional factors to consider with respect to clogging risks, which may require pre-treatment prior to injection.

In-channel modifications have been practiced since the 1960s in the Llobregat River in the Barcelona area by riverbed scarifications. Recently this technique experienced decreasing infiltration rates and it is planned to stop or to modify current practices in the near future. Currently this old technique is operated together with other complementary MAR techniques (ASR, infiltration ponds) in the Llobregat area of Spain (Hernández et al. 2015).

Until today, the expression "artificial recharge" has often been used. In Europe, this term dates back to the early investigators such as Richert (1900) and describes "underground" water recharged by human activities. Later on in the late 1990s and the beginning of the 21 st century the term 'managed aquifer recharge' was introduced. Some authors reason that "artificial recharge" falsely implies that a somewhat artificial process occurs (Dillon 2005), which can be misleading because the purification in the subsurface relies on natural processes. Moreover, the term MAR refers to the management of aquifer recharge, which implies that risks are managed in a quantitative way.

\section{Current situation of MAR in Europe}

The catalogue includes 224 MAR sites active in the year 2013, found in 23 European countries (Fig. 2).Most of the active MAR sites are found in Germany $(n=64)$ followed by the Netherlands $(n=41)$, France $(n=21)$, Finland $(n=14)$, Sweden $(n=11)$, Switzerland $(n=10)$ and Spain $(n=10)$, while in the other countries less than 10 active MAR sites have been found. The most widespread MAR type is induced bank filtration with 127 sites (57\% of total active sites); surface-spreading methods rank second among all MAR types with 77 sites (34\% of total active sites). Well injection schemes form the third largest group of MAR types with 11 active sites (5\% of total active sites) and 23 abandoned sites. Active-point or line-recharge and in-channel modification sites have been found 7 and 1 time(s), respectively. Enhanced storage MAR types, i.e., sub-surface dams, were not found in the literature for Europe.

The spatial occurrences of MAR sites and aquifer properties are shown in Fig. 3; these were derived from the International Hydrogeological Map of Europe ('IHME 1500') as reported in BGR \& UNESCO (2014). IHME 1500 is a generalized hydrogeological map series covering the European continent. Aquifer properties are displayed by their hydraulic productivity and dominant rock type.

The overwhelming majority $(n=150)$ of MAR sites included in the catalogue are situated in unconsolidated geological formations. It is clearly visible that the most common types of MAR are induced bank filtration and surfacespreading methods, located in central and northern countries where large perennial rivers and lakes exist. As shown by IHME 1500, Sweden, Finland, Norway and some parts of Denmark are characterized by local and limited groundwater availability or even essentially no groundwater (Fig. 3). In the Nordic countries, hard rock formations are widespread, while hydraulically conductive formations occur as small unconsolidated glacial deposits (e.g., esker, sander). The occurrence of conductive but small aquifers on one hand and the availability of surface water on the other hand is a main driver for the implementation of MAR (IAEA 2013). In the Nordic countries, surface-spreading methods dominate over induced bank filtration, because surface-spreading methods allow for groundwater replenishment to increase groundwater availability. In the Nordic countries, a special kind of surface spreading has been developed in the last years. Some sprinkling infiltration plants $(n=3)$ have been established, e.g., on forested
Fig. 2 Number of MAR sites and types for European countries (only MAR sites active in 2013 are shown)

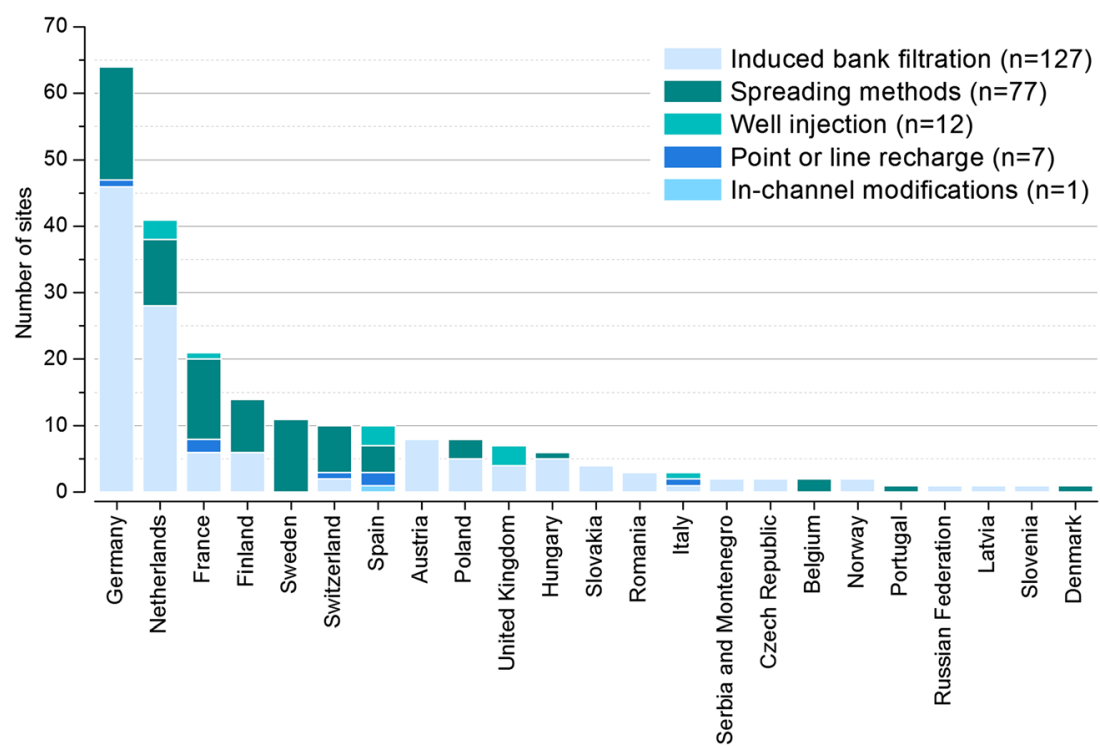


Fig. 3 Overview of MAR sites in Europe and simplified hydrogeological formations (Aquifer types reported in the International Hydrogeological Map of Europe, 'IHME 1500', BGR \& UNESCO 2014)

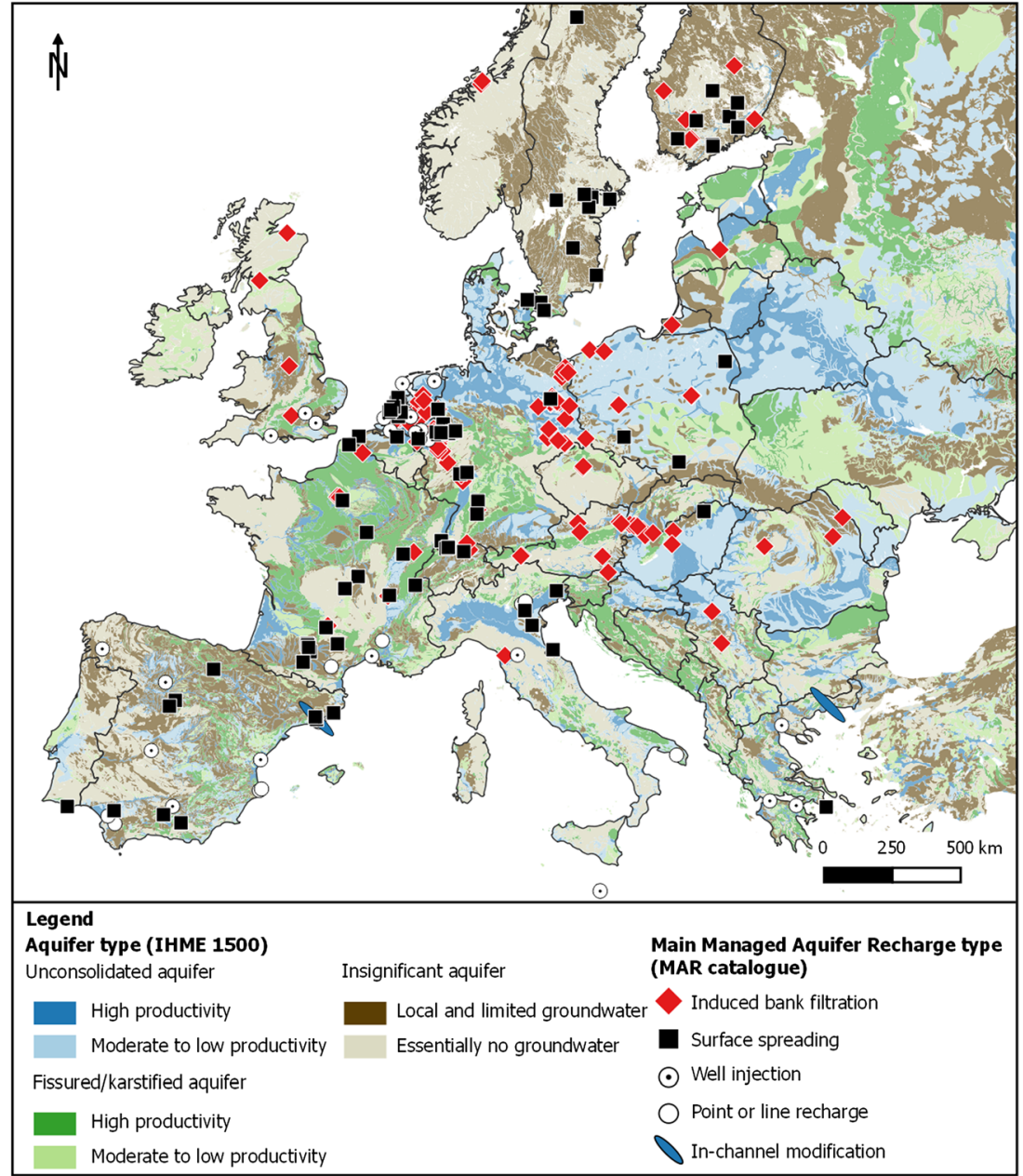

eskers in Finland (Helmisaari et al. 2005; Lindroos et al. 2002). Sprinkling irrigation (a subtype surface-spreading method) is envisaged to sustain higher dissolved oxygen concentrations in the recharge water in order to avoid anoxic conditions and associated dissolution of geogenic redoxsensitive compounds during subsurface passage. Helmisaari et al. (2005) also highlight that sprinkling irrigation does not cause much disturbance of the environment because the recharge water is "sprinkled directly onto the forest soil from a network of pipes and therefore does not cause as much direct disturbance to the vegetation and soil surface as, e.g., basin recharge". On the other hand, more land is required for sprinkling irrigation as compared to basin recharge, because the recharge areas in the forests are operated in alternating wet/ dry cycles. Apart from different types of surface-spreading methods in the Nordic countries, the MAR catalogue depicts a number of IBF sites which are, in contrast to IBF sites, in central Europe, mostly situated at lakes rather than rivers.

In central Europe-i.e., Belgium, the Netherlands, Germany, Poland, Czech Republic, Slovakia, Slovenia, France etc.-MAR sites are usually found in productive unconsolidated aquifers, e.g., in the North European plain in
North Germany and large parts of Poland, and along the major rivers. Clusters of MAR sites can be seen in the Netherlands, in Germany along the rivers Rhine and Elbe, in Berlin, and along the Danube River in Austria, Slovakia and Hungary. Most of the IBF sites from the catalogue are found in central Europe.

In the Mediterranean region-i.e., Spain, Italy and some parts of France - IBF sites are only marginally found, but some IBF sites are currently under development, e.g., in the Toscana region near Lucca, Italy (Rossetto et al. 2015). In the Mediterranean countries, mostly surface-spreading sites are found, but also in-channel modifications and point/line recharge schemes. Surface-spreading sites in this region are often designed without point of recovery and mainly aim to replenish the target aquifer, which is often used for agricultural purposes. At a site in Portugal (Campina de Faro aquifer system), river water was recharged through infiltration ponds in order to improve native groundwater quality (Ferreira et al. 2007).

\section{Source water type and end-use}

Potential source water types for MAR are river and lake water, stormwater, reclaimed water (treated effluent), desalinated 
water, and even groundwater from other aquifers or drinking water. The end-use describes the intended final usage of the water from the MAR scheme and includes agricultural, domestic (drinking water), environmental and industrial enduses. The number of MAR sites related to water end-use are shown in Fig. 4.

Figure 4a shows that most MAR sites producing domestic water rely on surface water as their source water, whereas Fig. $4 \mathrm{~b}$ shows which MAR type is producing for which enduse type. It lies in the nature of MAR that multiple end-uses may exist and a single end-use was sometimes difficult to define. Some sites, for example, do not recover the recharged water and the end-use is then attributed to the dominant usage of the target aquifer-e.g., if the aquifer is mainly used for drinking water abstraction, the end-use is then drinking water production. An environmental end-use is realized when the site is mainly for achieving environmental goals, e.g., sustaining groundwater dependent eco-systems or counteracting salinity ingress.

River and lake water are the most frequent source water types utilized for domestic drinking water supply to a large extent (Fig. 4a). The most frequent MAR type is induced bank filtration and has obviously two primary water sources: river and lake water (Fig. 4b). However, groundwater, which is in many cases of bank filtration also a source, is not shown here, despite the fact that native groundwater may contribute significantly to the abstracted water. Reclaimed water as source water is found at two active MAR sites. One MAR site uses this source water type for agricultural purposes in Spain (Ayuso-Gabella et al. 2011), and the other site produces domestic drinking water with reclaimed water in Belgium (van Houtte et al. 2012). In Torreele/St-Andre (Belgium), treated wastewater is infiltrated in a dune area. The MAR system, in combination with advanced technical pre-treatment, produces potable water in the range of $2.5 \times$
$10^{6} \mathrm{~m}^{3} / \mathrm{a}$ (van Houtte and Verbauwhede 2008). Another example for MAR using reclaimed water is found at the Llobregat aquifer in Barcelona (Spain), where reclaimed water was injected via injection wells to counteract seawater intrusion (Ortuno et al. 2012). This hydraulic barrier was in stand-by from 2011 (not shown in Fig. 4) due to financial constraints. The main reason for stopping the injection was the high costs of the (pre-)treatment of reclaimed water (a $15,000 \mathrm{~m}^{3} /$ day plant of ultrafiltration and reverse osmosis was constructed to improve reclaimed water quality before injection). Apart from this clearly communicated usage of reclaimed water by MAR, several other MAR sites exist which use treated wastewater or a blend of fresh and treated effluent water as source water. This de-facto use of reclaimed water is often found at MAR sites situated downstream of a sewage treatment plant, e.g., bank filtration at Berlin-Tegel (Germany) or at the infiltration pond in Sant Vicenç dels Horts (Spain).

MAR sites with a clear environmental end-use are rare and account only for $1 \%(n=3)$ of all active sites. In Germany, at an open-pit lignite mine (Garzweiler near Cologne), different surface-spreading techniques (e.g., infiltration shafts, wells) are operated by the mining company to stabilize the water table in order to preserve natural wetlands and swamps (RWE Power 2006); the majority of the source water is groundwater from the active mining area and it is then transported through a pipe network (ca. $125 \mathrm{~km}$ lengths) to the adjacent recharge areas to sustain the groundwater dependent eco-systems.

Not all potential source water types have been found to be utilized by European MAR sites. Stormwater run-off is not found as source water for MARs in Europe, and industrial end-use is found at three sites only (in Duisburg and Cologne in Germany, where IBF schemes are operated by industrial companies).
Fig. 4 a Source water types and b MAR types, in relation to enduses for MAR sites in the catalogue (only MAR sites active in 2013 are included)

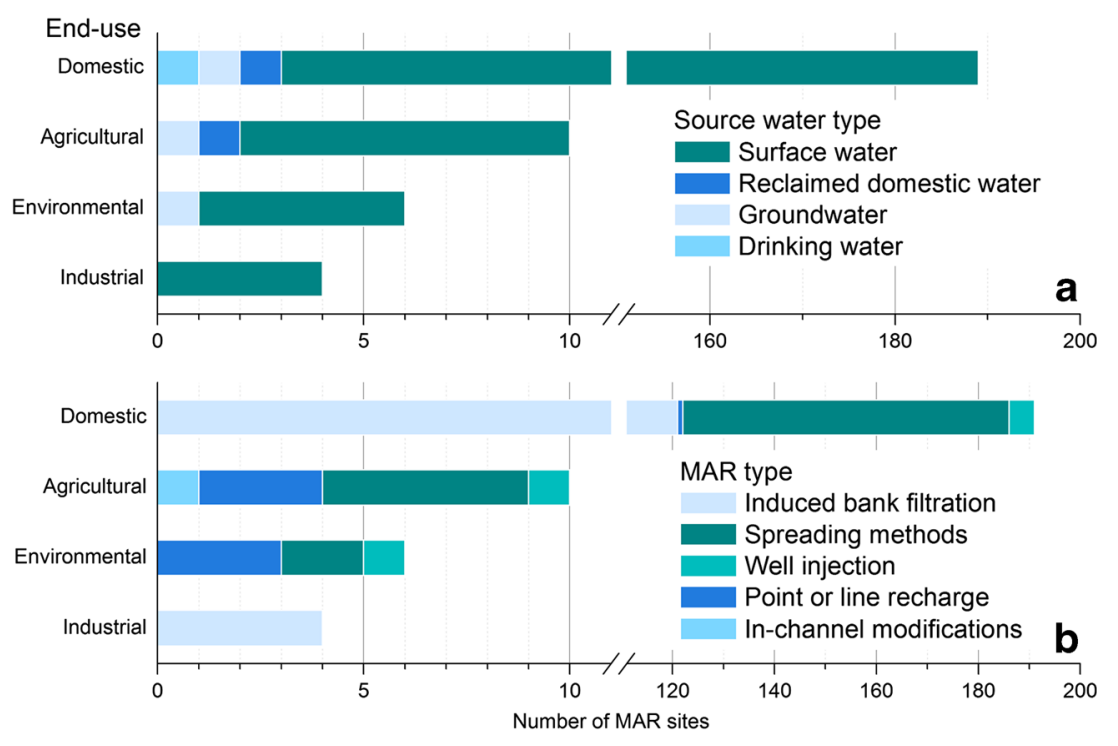




\section{Contribution of MAR to drinking water supply}

The volumetric contribution of MAR-derived water to the drinking water supply for European countries according to the operational scale of MAR sites is shown in Fig. 5. The operational scale gives insight into the total water quantity produced by the MAR scheme. Currently about 190 MAR sites in Europe produce drinking water (see Fig. 4) and are operated by water utilities (mostly public bodies). The percentage contribution of MAR-derived drinking water to drinking water supply is calculated with data from the European Environmental Agency for the year 2007 (EEA 2010).

The contribution of MAR-derived water to drinking water production varies greatly from country to country. In some countries, e.g., Hungary or Slovakia, MAR water may contribute $\geq 50 \%$ to the drinking water supply, while other countries, e.g., France, yield only $3 \%$ of their drinking water supply from MAR. Countries with a share of MAR-derived drinking water $<1 \%$ (e.g., Belgium or United Kingdom) are not shown in Fig. 5.

Some of the largest MAR sites exist on islands in the Danube River, upstream and downstream (IBF sites in Csepel and Szentendre) of Budapest in Hungary. The installed well capacity (indicating the operational scale) of these sites are reported to be 146 and $219 \times 10^{6} \mathrm{~m}^{3} / \mathrm{a}$, respectively
(Grischek et al. 2002). Along with all other MAR sites in Hungary included in the catalogue, the total drinking water volume derived from MAR is about $327 \times 10^{6} \mathrm{~m}^{3} / \mathrm{a}$, making up $\sim 50 \%$ of the public water (total public water supply $661 \times$ $10^{6} \mathrm{~m}^{3} / \mathrm{a}$, EEA 2010). Laszlo and Literathy (2002) estimated the share of riverbank filtrated water to the drinking water supply to be around $40 \%$ (in total $\sim 470 \times 10^{6} \mathrm{~m}^{3} / \mathrm{a}$ ), but the source of these figures remain unclear. Also the Slovakian public water supply relies on MAR to a large extent. The sum of operational scale for all Slovakian MAR sites (entirely IBF) makes up approx. $55 \%$ of total public water supply $\left(175 \times 10^{6} \mathrm{~m}^{3} / \mathrm{a}\right.$ from a total $\left.319 \times 10^{6} \mathrm{~m}^{3} / \mathrm{a}\right)$.

Especially in the Netherlands, different MAR types are used for drinking water production to a large extent. The sum of operational scale for all MAR sites producing drinking water in the Netherlands is about $295 \times 10^{6} \mathrm{~m}^{3} / \mathrm{a}$, contributing about $24 \%$ to the public water supply $\left(1,256 \times 10^{6} \mathrm{~m}^{3} / \mathrm{a}\right.$ from EEA 2010). According to the MAR catalogue, The Netherlands water supply relies on induced bank filtration (7.7\%), well injection (0.8\%) and spreading methods (15\%); Stuyfzand (1989) estimated that approx. 7\% of drinking water was produced by IBF systems (valid for the year 1981), which is quite similar to calculations from the MAR catalogue.

The catalogue includes 14 MAR sites from Finland with a total operational scale of $667 \times 10^{6} \mathrm{~m}^{3} / \mathrm{a}$. Total annual public

Fig. 5 Percentage contribution of MAR-derived drinking water (calculated from the MAR catalogue) to public water supply (taken from EEA 2010) for European countries. Countries with a MAR contribution $<1 \%$ are not shown. $N O$ Norway, $S E$ Sweden, FI Finland, DK Denmark, $N L$ The Netherlands, $B E$ Belgium, $D E$ Germany, $P L$ Poland, $C Z$ Czech Republic, $S K$ Slovakia, AT Austria, SI Slovenia, $H U$ Hungary, $C H$ Switzerland, $F R$ France, IT Italy, GB Great Britain

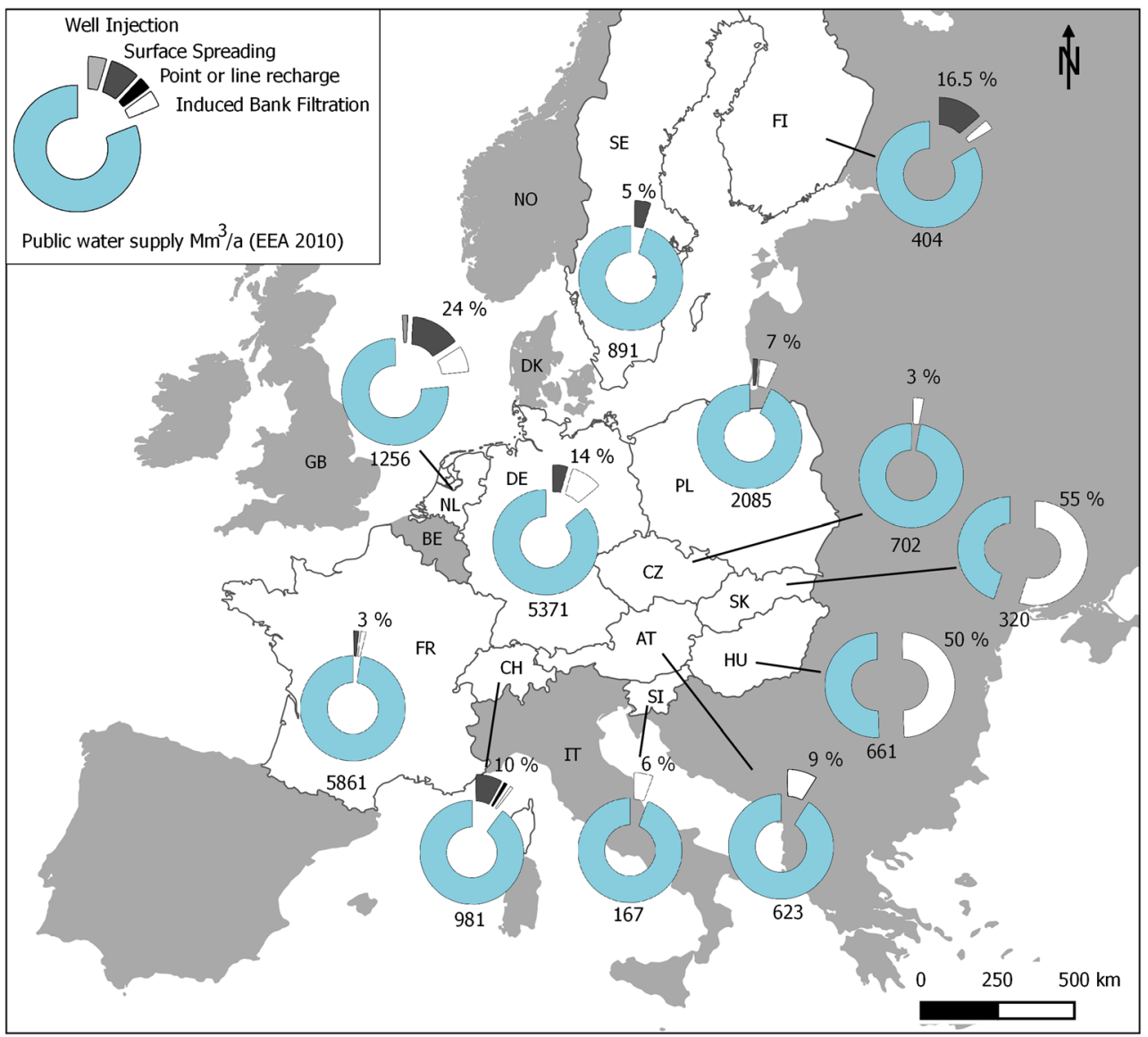


water supply in 2007 was $404 \times 10^{6} \mathrm{~m}^{3}$ (EEA 2010), which results in a contribution of $17 \%$ MAR water to public water supply. In the literature, estimations for the contribution of MAR water to the public water supply in Finland are in the range of $13-15 \%$ from IBF and surface-spreading sites in 2003 (Tapio et al. 2006). Helmisaari et al. (2005) estimated that MAR-derived water accounted for about $15 \%$ of the water distributed by Finnish water works in 2005 and is likely to increase to $20 \%$ by the year 2010 . Figures from the MAR catalogue come to quite similar estimations with $3 \%$ from IBF and $13.5 \%$ from surface-spreading sites.

For Germany, the catalogue includes 59 active MAR sites producing domestic water (42 sites with dominant induced bank filtration and 17 sites with dominant surface spreading). It should be noted that some water works, e.g., WW Flehe, WW Staad and WW Holthausen in Düsseldorf, are combined to a single site; hence, the real count of MAR sites is likely higher. However, the sum of operational scale from MAR sites in Germany producing drinking water makes up $746 \times 10^{6} \mathrm{~m}^{3} /$ a, which is about $14 \%$ of the total public water supply - public water supply 5,371 $\times 10^{6} \mathrm{~m}^{3} /$ a from EEA (2010). Schmidt et al. (2003) estimated that $16 \%$ of drinking water in Germany is produced by IBF and surface-spreading sites. Other calculations are found in StatBund (2013) - IBF water makes up $7.8 \%$ and surface-spreading sites $9.2 \%$, with a total contribution of $862 \times 10^{6} \mathrm{~m}^{3} / \mathrm{a}$; both of these published figures are slightly higher compared to calculations from the MAR catalogue, and may indicate some missing German MAR sites or underestimated operational scale. On the other hand, the operational scale for MAR sites is often based on estimations rather than exact measurements, and is therefore subject to variations. However, by looking on the city scale, e.g., in Berlin, the MAR catalogue includes eight active MAR sites producing about $135 \times 10^{6} \mathrm{~m}^{3} / \mathrm{a}$ of water, contributing $67 \%$ to the total water supply - water supply in Berlin is $202 \times 10^{6} \mathrm{~m}^{3} / \mathrm{a}$ in 2006 taken from Möller and Burgschweiger (2008). This proportion of MAR water for Berlin water supply is comparable to estimations from Schulze (1997), Hiscock and Grischek (2002) and Massmann et al. (2008b), given as 70-75\%.

The MAR catalogue includes eight sites producing domestic water in France. The sum of operational scale from these sites makes up approx. $3 \%$ of the public water supply in France-total public water supply $5,861 \times 10^{6} \mathrm{~m}^{3} / \mathrm{a}$ from EEA (2010). Other figures in the literature, such as $50 \%$ of bank filtered water in France (Doussan et al. (1997) and references therein), seem to exaggerate the share of MAR water for public water supply. This large contrast may be explained by different definitions of bank filtration among the countries. In France, production wells which are situated in alluvial strata were considered as surface water influenced and therefore categorized as riverbank filtration wells. This rough simplification may have led to the high share of RBF water, but the actual figures are likely lower.
The MAR catalogue lists nine sites in Switzerland producing domestic water with a total operational scale of approx. $100 \times 10^{6} \mathrm{~m}^{3} / \mathrm{a}$. Public water supply in 2007 was $981 \times$ $10^{6} \mathrm{~m}^{3} / \mathrm{a}$ (EEA 2010) yielding $10 \%$ contribution of MAR water. Diem et al. (2013) estimated that about $25-30 \%$ of drinking water originates from induced bank filtration alone in Switzerland. This catalogue entry comes to much lower proportions for all MAR schemes together and it remains unclear how this large difference may be explained.

\section{Aquifer properties and operational parameters}

Aquifer properties such as hydraulic conductivity and thickness of the target aquifer are highly important for MAR. Apart from this hydraulic data, the catalogue classifies target aquifers in consolidated and unconsolidated aquifers and aquifer confinement (confined, semi-confined, and unconfined). The target aquifers can further be differentiated by their specific aquifer properties describing the geological genesis of the aquifer (e.g., glacial, fluvial deposits) and the predominant pore type (unconsolidated, fractured, and karstified). Operational parameters are those parameters which can be, at least within the hydrogeological boundaries, controlled by the operator. Operational parameters include the lengths of the horizontal aquifer passage and achieved recovery rates. The horizontal aquifer passage is the modal distance between the point of recharge (e.g., river banks during induced bank filtration or the injection well during ASTR) and the point of recovery (the abstraction well). The recovery rate describes the volumetric ratio between the recharged and the recovered water. Representative properties, expressed as the 10th and 90th percentile, of target aquifer properties for surface spreading, induced bank filtration and well injection are shown in Table 2.

As shown already in Fig. 3, the overwhelming majority of MAR sites are situated in unconsolidated geological strata. MAR sites situated in consolidated geological media are found near London (UK) close to the Thames River where a fissured chalk aquifer (limestone) is hydraulically connected to the overlying riverbed deposits and used for IBF (Schijven et al. 2002). Other examples of MAR in consolidated media can be found in the Salento region in Italy (Ayuso-Gabella et al. 2011), some sites in Spain (Diaz Murillo et al. 2002) or the large ASTR scheme in north London (Harris et al. 2005). Evidence of MAR systems in karstified aquifers has not been found in the literature. Based on the data included in the catalogue, it was observed that MAR in consolidated aquifers is the exception in Europe. It can be concluded that the complex flow conditions and higher degree of heterogeneities (e.g., flow conduits, secondary porosity) require additional field investigations - an example of a tracer test at an ASR site in fissured chalk aquifer is given by Williams (2000). Moreover, 
Table 2 Representative properties of target aquifers and operational parameters for induced bank filtration, surface spreading and well injection techniques

\begin{tabular}{|c|c|c|c|}
\hline \multirow[t]{2}{*}{ Property } & \multicolumn{3}{|l|}{ MAR methodology } \\
\hline & Induced bank filtration & Surface spreading & Well injection \\
\hline (Hydro)geological properties ${ }^{\mathrm{a}}$ & $\begin{array}{l}\text { Unconsolidated, unconfined, } \\
\text { fluvio-glacial-detrital deposits }\end{array}$ & $\begin{array}{l}\text { Unconsolidated, unconfined, } \\
\text { fluvio-glacial-detrital deposits }\end{array}$ & $\begin{array}{l}\text { Unconsolidated, confined, } \\
\text { fluvio-glacial-detrital deposits }\end{array}$ \\
\hline Hydraulic conductivity $(\mathrm{m} / \mathrm{s})^{\mathrm{b}}$ & $5.5 \times 10^{-4}-5.5 \times 10^{-3}(n=67)$ & $3.1 \times 10^{-4}-5.5 \times 10^{-3}(n=28)$ & $2.7 \times 10^{-5}-3.3 \times 10^{-4}(n=3)$ \\
\hline Target aquifer thickness (m) ${ }^{\mathrm{b}}$ & $10-48(n=69)$ & $10-75(n=28)$ & $28-165(n=5)$ \\
\hline Horizontal aquifer passage $(\mathrm{m})^{\mathrm{b}}$ & $50-1,270(n=78)$ & $40-682(n=29)$ & NA \\
\hline $\begin{array}{l}\text { Residence time during subsurface } \\
\text { passage }(\mathrm{d})^{\mathrm{b}}\end{array}$ & $27-300(n=19)$ & $15-150(n=10)$ & NA \\
\hline Recovery rate/share of bank filtrate $(\%)^{\mathrm{b}}$ & $21-100(n=36)$ & $40-96(n=4)$ & NA \\
\hline
\end{tabular}

${ }^{\text {a }}$ Majority of sites for the respective MAR type

${ }^{\mathrm{b}} 10$ th and 90 th percentile;

NA not applicable

the limited purification capacity in consolidated aquifers compared to unconsolidated aquifers complicates the realization of MAR systems. Flow conduits may act as preferential flow paths which transport water with elevated flow velocities, thereby decreasing the residence time of infiltrated water in the subsurface. Residence time is known to be a crucial factor for many attenuation processes during MAR, e.g., microbial transport (Schijven et al. 2002) or pharmaceutical residues (Massmann et al. 2008a); hence, the overwhelming majority of MAR sites are situated in unconsolidated aquifers. Geological formations such as fluviatile and glacial sediments as well as aeolian deposits (e.g., in the Netherlands, Belgium) are commonly utilized. MAR sites situated in consolidated geological media are very rare and no MAR site in karstified strata was found.

Out of 127 IBF sites, 60 have been reported to be under unconfined conditions and 9 under semi-confined conditions, and out of 77 surface-spreading sites, 29 have been found to be under unconfined conditions and 4 semiconfined (for the remaining no information was found). Both MAR types require unconfined conditions and it must be assumed that sites where this specific information was not found are also under unconfined conditions. Well injection sites were often reported to be under confined conditions-for example, the ASR site in Barcelona-Cornellà is located between the phreatic aquifer (upstream) and the confined aquifer (downstream).

Induced bank filtration and surface-spreading techniques show a similar range of hydraulic conductivities. Well injection techniques indicate hydraulic conductivities approximately one order of magnitude lower, but the number of records is relatively low. Target aquifer thicknesses are also similar between IBF and surface-spreading sites. This finding is not surprising as many IBF and surface-spreading sites were developed conjunctively and are situated in the same aquifers.
The horizontal aquifer passage roughly relates to the residence time of the infiltrated source water in the subsurface, but is not equal to the flow path. The horizontal aquifer passage may also give insight on the share of source water abstracted by the recovery well(s). As a rule of thumb, a short horizontal aquifer passage within a thin aquifer implies short residence times and high shares of source water in the abstraction well. However, both parameters also depend on aquifer properties, well design and operational parameter for a particular site, which makes it challenging to assess residence times or share of source water based on horizontal aquifer passage alone. The data from the MAR catalogue show that IBF sites have a wide range of horizontal aquifer passages, from a few tens of meters-e.g., $20 \mathrm{~m}$ at the Eura IBF site in Finland (Kivimäki 2001) - to even a few kilometers such as the $3.5 \mathrm{~km}$ at Aalst IBF site in the Netherlands (Stuyfzand and Doomen 2004). Exceptionally long horizontal aquifer passages are found in the Netherlands where well fields, consisting of some 15-20 wells, are situated in a row perpendicular to the river bank. The horizontal distances reported by Stuyfzand et al. (2006a, 2006b) were measured between the central part of the well field and the riverbank during low flow conditions in summer. At other IBF sites, the well fields are situated in a row parallel to the river or lake bank-e.g., IBF in Berlin as described in Massmann et al. (2004). IBF sites with short aquifer passage are usually characterised by high shares of bank filtrate-e.g., Remmerden in the Netherlands with $82 \%$ (Stuyfzand and Doomen 2004). However, also IBF sites with long horizontal aquifer passages ( $\geq 3000 \mathrm{~m}$, e.g., Aalst, Kolff and Druten) may abstract substantial shares of bank filtrate (29-68\%) in their recovery well(s) (Stuyfzand et al. (2006a, 2006b). Analogous to IBF, the surface-spreading sites also show a wide range of horizontal aquifer passages, 
from $30 \mathrm{~m}$ at an infiltration pond in Poland (Blazejewski 1983 ) to $1,450 \mathrm{~m}$ at a sprinkler irrigation site in Finland (Lindroos et al. 2002). Only a little information about the horizontal aquifer passage and achieved recovery rates for well injection schemes was found and therefore not included in Table 2.

The residence time during MAR is a critical parameter to ensure sufficient attenuation of hygiene-related parameters and other undesired substances. From a hygiene perspective, a subsurface travel time of around 50-60 days (in the UK 400 days are defined as the outer source protection zone) are often demanded by European directives (Chave et al. 2006; DVGW 2006). Representative values from the MAR catalogue shows that residence time for some IBF sites can be substantially shorter than 5060 days. It has to be taken into account that travel-time estimations are subject to large variations depending on the assessment method applied. Travel time estimations based on only hydraulic data must be considered less accurate than estimations based on tracer breakthrough curves. However, median values for IBF and surfacespreading sites were calculated to be 70 and 55 days, respectively.

Recovery rates for surface-spreading sites were often not reported in the literature and found only at four sites. Whenever possible, this value was calculated based on information from the literature source, e.g., at the Solleveld site (infiltration ponds in dune areas in the Netherlands), the average annual abstracted water volume is lower than the average annual infiltrated volume and the overall recovery rate was approximated to be $90 \%$. For IBF systems, the share of bank filtrate describes the volumetric ratio between bank filtrate and native groundwater in the recovery well(s). Information about the share of bank filtrate was found at 36 IBF sites and ranges from minimum $10 \%$ to maximum $100 \%$, resulting in representative values of $21-100 \%$ (10th and 90th percentile, respectively).

\section{Perspective of MAR in Europe and conclusions}

For over a century, various forms of managed aquifer recharge have been used in Europe. This development has occurred autonomously, with "trial-and-error" within the full range of climatically and hydrogeologically diverse conditions of the European countries. Although, over the years, the use of MAR has grown and spread independently throughout Europe in support of the EU strategy for resource and energy efficient water production and management (EEA 2014), the benefits of MAR could develop towards it becoming a "first-option" in securing water availability for the future. In the face of numerous stresses on the availability of water such as climate change, increased weather variability, salinization, as well as increased urbanization of coastal zones and emerging substances, MAR has the potential to facilitate optimal (re)use and storage of available water resources and to take advantage of the natural purification and low energy requirements during MAR operations. Particularly with respect to the re-use of wastewater treatment-plant effluent and stormwater, which is currently underdeveloped, the use of MAR can support the public acceptance of such water-resource efficient schemes.

In developing water availability strategies in the face of numerous challenges, Europe is not alone; worldwide, MAR is being considered as an integral and essential technique to meet objectives and demands for the future - e.g., Sheng and Zhao (2014); Megdal et al. (2014); Dillon et al. (2010). As globally, the pressure on freshwater supplies increases by growing water demand, intensified by continued urbanization, increased agricultural needs for food production and the desire to preserve ecosystem integrity, MAR is expected to be increasingly relied on.

The most densely populated and (economically) productive regions of the world are in the coastal zones, particularly in Europe along the Mediterranean Sea and the North Sea. It was estimated that about half of the world's population lives within $200 \mathrm{~km}$ of a coastline (UN 2010). While these areas produce many economic benefits, the associated high water demand puts tremendous pressure on freshwater resources and coastal ecosystems, leading to problems like seasonal water shortage, overexploitation of groundwater resources, saltwater intrusion, and disappearance of wetlands. Further economic growth, population increase, and climate change will aggravate these problems, ultimately blocking the sustainable development of coastal zones in industrialized, emerging, and developing countries (EC 2012); therefore, in 2015, water crises were identified as the main global risk (WEF 2015).

Traditionally, aboveground solutions such as construction of reservoirs or saltwater desalination are often sought to solve freshwater problems. However, the subsurface may provide more robust, effective, sustainable, and cost-efficient freshwater management solutions - for instance, artificial recharge of aquifers with temporary freshwater surpluses is increasingly applied worldwide for water storage and treatment (Dillon et al. 2010). Typically, artificial recharge in unconfined aquifers is used to increase volumetric water availability by filling part of the overlying unsaturated zone. In (semi)confined aquifers, however, artificial recharge can also increase water availability by displacing native groundwater that is not suitable or less suitable for use than the water source available for storage. In fact, ASR and ASTR have been in confined/semiconfined aquifers, in Europe and beyond. Depending on the intended use, a wide range of water quality parameters-e.g., the presence of manganese, Antoniou et al. (2014) — can make 
native groundwater less suitable; however, in recent years, particular attention has been on the artificial recharge of freshwater in water-stressed areas with brackish or saline native groundwater (Ward et al. 2007, 2009). These studies have highlighted the impact of the density difference between the injected fresh and native saline water on recovery efficiencies, and recent advances using either horizontal or multiple partially penetrating wells enable the improved recovery in both confined and unconfined saline aquifers (Zuurbier et al. 2014a, b, 2016).

During data compilation for the MAR catalogue, it was realized that clear economic case studies of European MAR sites are often not available. Economic feasibility can be evaluated using cost-benefit analysis, but site specifics and multiple benefits of MAR are often challenging to monetize. The lack of data for economic feasibility of the various types of MAR due to the wide range of benefits is considered to be a major barrier for implementation; however, recent nonEuropean studies about MAR economics related to water reuse (Vanderzalm et al. 2015), and conceptual frameworks for MAR economics including methods for monetizing typical MAR benefits (Maliva 2014), are readily applicable to European sites.

Aquifer storage and recovery (ASR) for instance can be a successful technique for storage and recovery of both potable and irrigation water (Maliva and Missimer 2010); however, as in other areas in the world, it has not reached its full potential in Europe. The advantages of ASR consist of the limited space requirement above ground, the lack of losses by evaporation, the protection from atmospheric, biologic and anthropogenic contamination, and the protection from earthquake damagefor example, in the Netherlands, this increased ASR reliability is very much welcomed with the prospects of longer periods of drought, despite an increase in yearly gross precipitation (KNMI 2014) induced by climate change, while water is increasingly recognized as a scarce resource (WEF 2015). The need for water harvesting and storage is therefore expected to increase; furthermore, an increase in extreme rainfall events is expected in the Netherlands (KNMI 2014; Royal Netherlands Meteorological Institute 2014), which will require better exploitation of aboveground water reservoirs for retention of intense rainfall. ASR provides the means to lower the levels of these reservoirs by early infiltration once potential extreme rainfall events are predicted, and to provide retention, without having to discharge (and loose) the water to the sea. Therefore, the water remains available for later times of demand, while the unrecoverable part can counteract the ongoing salinization. Another European example from the coastal zone is Spain (e.g., the Llobregat aquifer in Barcelona) where MAR is considered as a promising technique to be implemented at a large scale using reclaimed water to improve groundwater availability without compromising surface-water availability for direct users.
Acknowledgements This study has received funding from the 7 th Framework Programme of the European Union under the grant agreement number 308339 within the DEMEAU project.

Open Access This article is distributed under the terms of the Creative Commons Attribution 4.0 International License (http:// creativecommons.org/licenses/by/4.0/), which permits unrestricted use, distribution, and reproduction in any medium, provided you give appropriate credit to the original author(s) and the source, provide a link to the Creative Commons license, and indicate if changes were made.

\section{References}

Antoniou EA, Hartog N, van Breukelen BM, Stuyfzand PJ (2014) Aquifer pre-oxidation using permanganate to mitigate water quality deterioration during aquifer storage and recovery. Appl Geochem 50:25-36

Ayuso-Gabella N, Page D, Masciopinto C, Aharoni A, Salgot M, Wintgens T (2011) Quantifying the effect of managed aquifer recharge on the microbiological human health risks of irrigating crops with recycled water. Agric Water Manag 99:93-102

Azcon A, Dolz J (1978) Estudio de la recarga artificial mediante pozos en Cornellà [Study of artificial recharge by wells in Cornellà]. XII Curso Internacional Hidrología Subterránea [XII International Course Subsurface Hydrology], FCIHS, Barcelona

BGR \& UNESCO (eds.) (2014): International Hydrogeological Map of Europe 1:1,500,000 (IHME1500). Digital map data v1.1. Hannover/ Paris.

Blazejewski M (1983) Perspektywy Wykorzystania Sztucznej Infiltracji W Uzadatnianiu Zanieczyszonych Wod Powierzchniowych W Polsce W Swietle Dotychczasowych Doswiadczen [Perspectives of artificial recharge to treat contaminated groundwater in Poland]. Sztuczna infiltracja w uzdatnianiu WOD powierzchniowych [Experiences with artificial recharge]. Instytut Ksztaltowania Srodowiska (Institute of Environmental Science) - Poznan, Poland, pp 7-12

BMI (1985) Künstliche Grundwasseranreicherung: Stand der Technik und des Wissens in der Bundesrepublik Deutschland. Bundesministerium des Inneren [Artificial groundwater replenishment: state of the technology and knowledge in the Federal Republic Germany, Ministry of the Interior]. Schmidt, Berlin

Chave P, Howard G, Schijven J, Appleyard S, Fladerer F, Schimon W (2006) Groundwater protection zones. In: Schmoll O, Howard G, Chilton J, Chorus I (eds) Protecting groundwater for health: managing the quality of drinking-water sources. IWA, London

Diaz Murillo JM, de la Orden G, Lopez Geta JA, Rubio Campos A, Gonzalez Ramon Martin Machuca A (2002) Lessons from groundwater recharge projects in Spain: management of aquifer recharge for sustainability. In: Dillon P (ed) International Symposium on Artificial Recharge of Groundwater (ISMAR), Adelaide, September 2002, pp 393-398

Diem S, Schrirmer M, von Rohr MR, Kohler H-P, Hering JG, von Gunten U (2013) Qualität des Uferfiltrats: Einfluss der Klimabestimmten Variablen Temperatur und Abfluss [Quality of bank filtrate: influence of the climate induced variables temperature and discharge]. Aqua \& Gas 11, Eawag, Dübendorf, Switzerland, $21 \mathrm{pp}$

Dillon P (2005) Future management of aquifer recharge. Hydrogeol J 13: 313-316

Dillon P, Toze S, Page D, Vanderzalm J, Bekele E, Sidhu J, Rinck-Pfeiffer S (2010) Managed aquifer recharge: rediscovering nature as a leading edge technology. Water Sci Technol 62:2338-2345

Doussan C, Poitevin G, Ledoux E, Detay M (1997) River bank filtration: modelling of the changes in water chemistry with emphasis on nitrogen species. J Contam Hydrol 25:129-156 
DVGW (2006) Richtlinien für Trinkwasserschutzgebiete; Teil 1: Schutzgebiete für Grundwasser - Arbeitsblatt W 101. Deutscher Verein des Gas- und Wasserfaches [Guidelines for drinking water protection zones, part 1: protection zones for groundwater. Issue W101. German Association for Gas and Water]. DVGW, Bonn, Germany

EC (2012) A blueprint to safeguard Europe's water resources. European Commission, Brussels, Belgium

EEA (2010) European Environmental Agency Core Set Indicator CSI 18, based on data from Eurostat data table: annual water abstraction by source and by sector. European Environmental Agency, Copenhagen

EEA (2014) Performance of water utilities beyond compliance: sharing knowledge bases to support environmental and resource-efficiency policies and technical improvements. European Environmental Agency, Copenhagen

Ferreira JPL, Oliveira M, Diamantino C, João Moinante M, Medeiros A (2007) DELIVERABLE 31: inventory of alternative water sources for each test site. In: GABARDINE Project: groundwater artificial recharge based on alternative sources of water-advanced integrated technologies and management. National Laboratory for Civil Eng., Lisbon

Grischek T, Schoenheinz D, Worch E, Hiscock K (2002) Bank-filtration in Europe: an overview of aquifer conditions and hydraulic controls. In: Dillon P (ed) Management of aquifer recharge for sustainability: proceedings of the 4th International Symposium on Artificial Recharge of Groundwater, Adelaide, September 2002. CRC, Boca Raton, FL, pp 485-488

Hannappel S, Scheibler F, Huber A, Sprenger C (2014) M11.1 Characterization of European Managed Aquifer Recharge (MAR) sites: analysis. DEMEAU. http://demeau-fp7.eu/. Accessed February 2017

Harris SJ, Adams MJ, Jones MA (2005) NLARS: evolution of an artificial recharge scheme. ISMAR5, Berlin, June 2005

Helmisaari HS, Derome J, Hatva T (2005) Artificial recharge in Finland through basin and sprinkling infiltration: soil process, retention time and water quality. International Symposium on Management of Aquifer Recharge, Berlin

Hernández M, Camprovín P, Bernat X, Massana J, Castelló J (2015) ASR en Barcelona: Nuevo régimen de operación para hacer frente a nuevos escenarios [ASR in Barcelona: New operating regime to deal with new scenarios]. IV Jornadas de Ingeniería del Agua La precipitación y los procesos erosivos, Cordoba, October 2015

Hiscock KM, Grischek T (2002) Attenuation of groundwater pollution by bank filtration. J Hydrol 266:139-144

Homonnay Z (2002) Use of bank filtration in Hungary. In: Ray C (ed) Riverbank filtration: understanding contaminant biogeochemistry and pathogen removal. Kluwer, Dordrecht, Germany, pp 221-228

IAEA (2013) Using isotopes for design and monitoring of artificial recharge systems. International Atomic Energy Agency, Vienna

IGRAC (2016) Global MAR Inventory, International Groundwater Resources Assessment Centre. https://www.un-igrac.org/specialproject/global-mar-inventory. Accessed 1 Nov 2016

Kivimäki AL (2001) Site description Jokioinen, Forssa and Eura, Finland, Artificial recharge of groundwater. EC project ENV4CT95-0071, EC, Brussels, pp 23-25

KNMI (2014) Climate Change scenarios for the 21st Century: a Netherlands perspective. In: van den Hurk B, Siegmund P, Klein Tank A (eds) Royal Netherlands Meteorological Institute, De Bilt, The Netherlands

Laszlo F, Literathy P (2002) Laboratory and field studies of pollutant removal. In: Ray C (ed) Riverbank filtration: understanding contaminant biogeochemistry and pathogen removal. Kluwer, Dordrecht, The Netherlands, pp 229-234
Lindroos A-J, Kitunen V, Derome J, Helmisaari H-S (2002) Changes in dissolved organic carbon during artificial recharge of groundwater in a forested esker in southern Finland. Water Res 36:4951-4958

Maliva RG (2014) Economics of managed aquifer recharge. Water 6(5): $1257-1279$

Maliva RG, Missimer TM (2010) Aquifer storage and recovery and managed aquifer recharge using wells: planning, hydrogeology, design and operation. Methods in Water Resources Evolution. Schlumberger, Houston, TX

Massmann G, Knappe A, Richter R, Pekdeger A (2004) Investigating the influence of treated sewage on groundwater and surface water using wastewater indicators in Berlin, Germany. Acta Hydrochim Hydrobiol 32:336-350

Massmann G, Dünnbier U, Heberer T, Taute T (2008a) Behaviour and redox sensitivity of pharmaceutical residues during bank filtration: investigation of residues of phenazone-type analgesics. Chemosphere 71:1476-1485

Massmann G, Sültenfuß J, Dünnbier U, Knappe A, Taute T, Pekdeger A (2008b) Investigation of groundwater residence times during bank filtration in Berlin: a multi-tracer approach. Hydrol Process 22:788801

Megdal S, Dillon P, Seasholes K (2014) Water banks: using managed aquifer recharge to meet water policy objectives. Water 6:1500

Möller K, Burgschweiger J (2008) Wasserversorgungskonzept für Berlin und für das von den BWB versorgte Umland (Entwicklung bis 2040) [Water supply concept for Berlin and the surrounding area (development until 2040) supplied by BWB]. BWB, Berlin

Ortuno F, Molinero J, Custodio E, Juárez I, Garrido T, Fraile J (2012) Seawater intrusion barrier in the deltaic Llobregat aquifer (Barcelona, Spain): performance and pilot phase results. SWIM21 - 21st Salt Water Intrusion Meeting 21, Azores, Portugal, June 2010, pp 135-138

RWE Power (2006) Ökologie im Nordrevier: Wasser für die Feuchtgebiete [Ecology in the Nordrevier: water for the wetlands]. RWE Power, Essen, Germany

Pyne D (2005) Aquifer storage recovery: a guide to groundwater recharge through wells. ASR Systems, Gainesville, FL

Ray C, Schubert J, Linsky RB, Melin G (2002) Introduction. In: Ray C (ed) Riverbank filtration: improving source-water quality. Kluwer, Dordrecht, The Netherlands

Richert JG (1900) On artificial underground water. C. E. Fritze's Royal Book-Store, Stockholm

Rojanschi V, Mlenajek L, Stanciulescu M (2002) Riverbank filtration in water supply: old solutions, new problems. In: Ray C (ed) Riverbank filtration: understanding contaminant biogeochemistry and pathogen removal. Kluwer, Dordrecht, The Netherlands, pp 235-245

Rossetto R, Barbagli A, Borsi I, Mazzanti G, Vienken T, Bonarim E (2015) Site investigation and design of the monitoring system at the Sant'Alessio Induced RiverBank Filtration plant (Lucca, Italy). Rend Online Soc Geol Ital 35:248-251

Royal Netherlands Meteorological Institute (2014) KNMI'14 climate scenarios for the Netherlands: guideline for professionals in climate adaptation. KNMI, De Bilt, The Netherlands, 34 pp

Schijven J, Berger P, Miettinen I (2002) Removal of pathogens, surrogates, indicators, and toxins using riverbank filtration. In: Ray C, Melin G, Linsky RB (eds) Riverbank filtration: improving sourcewater quality. Springer, Heidelberg, Germany, pp 73-116

Schmidt CK, Lange FK, Brauch H-J, Kühn W (2003) Experiences with riverbank filtration and infiltration in Germany. DVGW-Water Technology Center (TZW), Karlsruhe, Germany, 17 pp

Schulze D (1997) Wassermengenwirtschaft im Ballungsraum Berlin [Water quantity economy in the conurbation area Berlin]. Arch Nat Lands 35:289-300 
Sheng Z, Zhao X (2014) Special issue on managed aquifer recharge: powerful management tool for meeting water resources challenges. J Hydrol Eng. doi:10.1061/(ASCE)HE. 1943-5584.0001139

StatBund (2013) Öffentliche Wasserversorgung und öffentliche Abwasserentsorgung: öffentliche Wasserversorgung [Public water supply and public sanitation: public water supply]. Statistisches Bundesamt, Wiesbaden, Germany

Stuyfzand PJ (1989) Hydrology and water quality aspects of Rhine bank groundwater in the Netherlands. J Hydrol 106:341-363

Stuyfzand PJ, Doomen A (2004) The Dutch experience with MARS (Managed Aquifer Recharge and Storage): a review of facilities, techniques and tools. KIWA NV, Rijswijk, The Netherlands

Stuyfzand P, Juhàsz-Holterman MA, de Lange W (2006a) Riverbank filtration in the Netherlands: well fields, clogging and geochemical reactions. In: Hubbs SA (ed) Riverbank filtration hydrology. Springer, Dordrecht, The Netherlands, pp 119-153

Stuyfzand PJ, Juhasz-Holterman MHA, de Lange WJ (2006b) Riverbank filtration hydrology. In: Hubbs SA (ed) Riverbank filtration hydrology. Springer, Dordrecht, The Netherlands, pp 119-153

Stuyfzand PJ, Nienhuis P, Antoniuou A, Zuurbier K (2012) Haalbaarheid van ondergrondse berging via $\mathrm{A}(\mathrm{S} / \mathrm{T}) \mathrm{R}$ in Hollands kustduinen [Feasibility of underground storage through A $(\mathrm{S} / \mathrm{T}) \mathrm{R}$ in Dutch coastal dunes]. KWR, Nieuwegein, The Netherlands

Tapio SK, Annukka Lipponen M, Rönkö EKT (2006) Groundwater use and policy in community water supply in Finland. Hydrogeol J 14: 69-78

UN (2010) United Nations atlas of the oceans. UN, New York

van Houtte E, Verbauwhede J (2008) Operational experience with indirect potable reuse at the Flemish Coast. Desalination 218:198-207

van Houtte E, Cauwenberghs J, Weemaes M, Thoeye C (2012) Indirect potable reuse via managed aquifer recharge in the Torreele/St-Andre project. In: Kazner C, Wintgens T, Dillon P (eds) Water reclamation technologies for safe managed aquifer recharge. IWA, London, pp 33-33

Vanderzalm JL, Dillon PJ, Tapsuwan S, Pickering P, Arold N, Bekele EB, Barry KE, Donn MJ, McFarlane D (2015) Economics and experiences of managed aquifer recharge (MAR) with recycled water in Australia. Australian Water Recycling Centre of Excellence, Brisbane

Ward JD, Simmons CT, Dillon PJ (2007) A theoretical analysis of mixed convection in aquifer storage and recovery: how important are density effects? J Hydrol 343:169 - 186. doi:10.1016/j.jhydrol.2007.06.011

Ward JD, Simmons CT, Dillon PJ, Pavelic P (2009) Integrated assessment of lateral flow, density effects, and dispersion in aquifer storage and recovery. J Hydrol 370:83- 99. doi:10.1016/ j.hydrol.2009.02.055

WEF (2015) Global risks 2015. World Economic Forum, Davos, Switzerland

Williams A (2000) Using an aquifer storage and recovery (ASR) trial as a large-scale tracer test. TraM'2000, Liege, Belgium

Zuurbier K, Kooiman J, Groen M, Maas B, Stuyfzand P (2014a) Enabling successful aquifer storage and recovery of freshwater using horizontal directional drilled wells in coastal aquifers. J Hydrol Eng 20: B4014003

Zuurbier KG, Zaadnoordijk WJ, Stuyfzand PJ (2014b) How multiple partially penetrating wells improve the freshwater recovery of coastal aquifer storage and recovery (ASR) systems: a field and modeling study. J Hydrol 509:430-441

Zuurbier KG, Hartog N, Stuyfzand PJ (2016) Reactive transport impacts on recovered freshwater quality during multiple partially penetrating wells (MPPW-)ASR in a brackish heterogeneous aquifer. Appl Geochem 71:35-47 